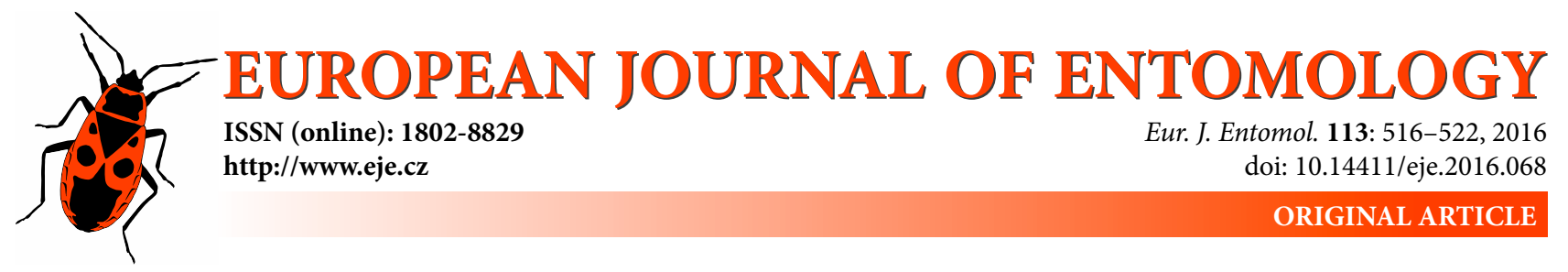

\title{
Host plants and aphid hosts influence the selection behaviour of three aphid parasitoids (Hymenoptera: Braconidae: Aphidiinae)
}

\author{
Loulou ALBITTAR ${ }^{1}$, Mohannad ISMAIL ${ }^{2}$, Claude BRAGARD ${ }^{1}$ and ThierRy HANCE ${ }^{1}$ \\ ${ }^{1}$ Earth and Life Institute, Biodiversity Research Centre, Université Catholique de Louvain, Louvain-la-Neuve, Belgium; \\ e-mails: louloual@yahoo.fr, claude.bragard@uclouvain.be,thierry.hance@uclouvain.be \\ ${ }^{2}$ Wuhan Botanical Garden/Institute, Chinese Academy of Sciences, Wuhan, China; e-mail: mohannad.ismail1@gmail.com
}

Key words. Aphidiinae, Aphididae, aphid, broad bean, host preference, parasitoid, plant influence, sugar beet

\begin{abstract}
Aphis fabae and Myzus persicae (Hemiptera: Aphididae) are insect pests that damage sugar beet and bean crops. Both are responsible for losses in yield and transmission of viral diseases, and may be present on the same host at the same time. Three parasitoid species, Aphidius colemani, Lysiphlebus testaceipes and Lysiphlebus fabarum (Hymenoptera: Braconidae: Aphidiinae) have the potential to be used as biological control agents against at least one of these species of aphids. As a first step prior to the implementation of a biological control program, our aim was to understand the host selection behaviour of the parasitoids, particularly when both aphids are present. We recorded the host acceptance (number of insertions of the ovipositor / number of antennal contacts), suitability (number of mummies / the number of insertions of the ovipositor) and emergence (number of adults emerging from mummies) of these three aphid parasitoids when parasitizing the two aphids. We also analyzed the effect of the host plant on the host preference of the parasitoid. Females of each parasitoid species $(n=15)$ were exposed to 20 aphids of $A$. fabae or M. persicae, or a mixture of these two species of aphids, for $15 \mathrm{~min}$, on a leaf disc of each of the two host plants, sugar beet and bean. Higher host acceptance and suitability were recorded for $A$. colemani attacking both species of aphid: A. fabae (43 and 46\%) and M. persicae (43 and 46\%) on beet and bean plants respectively, compared to $L$. testaceipes and $L$. fabarum. L. testaceipes and $L$. fabarum showed a clear preference for $A$. fabae. L. fabarum accepted $M$. persicae on both plants only when it was mixed with $A$. fabae, probably due to a confusion effect. We found that the host plant played a significant role in host acceptance, host suitability. We conclude that $A$. colemani is the better of the three parasitoids studied for the biological control in bean, and particularly, sugar beet crops.
\end{abstract}

\section{INTRODUCTION}

Aphids are among the most important crop pests worldwide (Bonnemain, 2010) and fifty species are of economic importance (Turpeau et al., 2013). Aphid pests are often generalists and facultatively or obligatorily change host plants during their life cycle and thrive on several secondary hosts, including crop plants and wild species. The two main species of aphids on sugar beet crops in Europe are the black bean aphid Aphis fabae (Scopoli) (Hemiptera: Aphididae) and the peach potato aphid Myzus persicae (Sulzer) (Hemiptera: Aphididae) (Jadot, 1974, Smith \& Hallsworth, 1990). In Europe it is estimated that aphids on sugar beet are responsible for an annual loss of 2 million tonnes (Wellings et al., 1989). Both M. persicae and $A$. fabae affect plant growth and the storage of sugars (Clover et al., 1999, Simpson et al., 2012) directly by sucking plant sap and indirectly by transmitting plant viruses. The beet yellow virus and the beet mild yellow virus can cause yield losses of up to $50 \%$ and $35 \%$, respectively (Smith et al., 1991).
To limit the damage and resultant economic losses caused by aphids it is essential to control populations and reduce their spread (Turpeau et al., 2013). Several methods have been used to combat aphids. Currently, control of beet aphids is still largely based on preventive systemic insecticide treatments of seed, but changes in pesticide regulations due to the negative effects of these chemicals necessitate the development of other control strategies. Biological control is considered a good alternative and the use of aphid parasitoids is promising (Boivin et al., 2012). For wheat it has been shown that releasing 20,000 individuals of the parasitoid Aphidius rhopalosiphi (De Stefani-Peres) (Hymenoptera: Aphidiinae) / ha can decrease the population of the grain aphid Sitobion avenae (Fabricius) (Hemiptera: Aphididae) below the economic threshold (Levie et al., 2005). Biological control of aphids using parasitoids has not yet been tested extensively on sugar beet and it is suggested that the use of biocontrol agents to reduce populations of potential vectors would not necessarily prevent the transmission of viruses (Bragard et al., 2013). 
The success of a biological control program depends on the capacity of the parasitoid to recognize and parasitize its host. Therefore, it is important to understand the behaviour of the parasitoid in selecting its principal and alternative hosts in a crop, prior to any release in the field (Dorn et al., 1999, Hopkinson et al., 2013). Successful parasitism requires a series of interactions among parasitoids, their hosts and host plants, including habitat finding, host location, host acceptance, host suitability and host regulation (Vinson, 1976, 1984; Hatano et al., 2008; Rasekh et al., 2010). Parasitoids may respond to semiochemical cues during antennal contact and ovipositor probing (Muratori et al., 2006; Larocca et al., 2007) and volatile chemical compounds emitted by damaged plants (Turlings et al., 1990, Mattiacci et al., 1994, Dicke et al., 2003). Host selection by parasitoids may be influenced by the insect host, the plant on which the insect hosts are feeding and by conditioning of females to the host on which they developed (Chau \& Mackauer, 2001). Moreover, selection behaviour of the parasitoids can be modified according to the physiological status of the parasitoid, such as egg load at emergence (Desneux et al., 2009) and previous experience. Female parasitoids that are time limited with high egg loads are more likely to accept less suitable hosts than females with low egg loads and a high life expectancy (Hopper et al., 2013).

Three parasitoid species are currently recorded parasitizing A. fabae and M. persicae in the field: Aphidius colemani (Viereck), Lysiphlebus testaceipes (Cresson) and $L$. fabarum (Marshall) (Hymenoptera: Aphidiinae). They are reported to respond to a variety of both contact and olfactory cues associated with the host or its habitat (Jang et al., 2000; Carver \& Franzmann, 2001). The parasitoid $A$. colemani appears to be a species complex in which different geographic populations may vary genetically and have different patterns of host preference (Stary, 1975; Messing \& Rabasse, 1995; Ode et al., 2005). It is now produced commercially and has been used in many biological control programs against various important aphid pests, such as $M$. persicae in greenhouses (Grasswitz, 1998, Boivin et al., 2012). For inundate release in greenhouses mummies are placed at the base of the plants. According to Grasswitz (1998) the newly emerged adults from these mummies may lack early post-eclosion experiences, which can affect their foraging behaviour.

L. testaceipes is a generalist parasitoid that has a broad range of hosts (Mackauer \& Stary, 1967) with various preferences for different aphids on several plants (Knight, 1944; Sekhar, 1960). L. fabarum is the most abundant parasitoid of $A$. fabae in agroecosystems. It causes a considerable reduction of the abundance of $A$. fabae and thus could be useful in the biological control of this pest (Völkl, 1992). It is a multivoltine species and mainly thelytokous in central Europe (Nemec \& Stary, 1985).

To our knowledge, few studies have been conducted on aphid parasitoids in sugar beet fields. M. persicae and $A$. fabae are characterized by very wide host ranges and are adapted to feed on a large number of plant families and species (Jadot \& Roland, 1971; Fernandez-Quintanilla et al., 2002), including sugar beet. Weeds around cultivated fields play a significant role in the build-up of aphid populations (Dufus, 1971). As the host plant may influence parasitoid acceptance, plant hosts must be considered when assessing the behaviour of the three most common parasitoid species of sugar beet aphids. Biocontrol agents are usually reared continuously on one host species and on one host plant, but they are released to control several pests on several host plants. For this reason, our aim was to determine whether rearing parasitoids on one host aphid species and one host plant species would affect future preference of the parasitoids for different hosts.

In order to select the best species for parasitoid augmentation, several traits need to be evaluated. In this study, because released parasitoids would be required to control two aphid species (A. fabae and M. persicae), we first compared the host acceptance behaviour and the suitability for the parasitoids (A. colemani, L. testaceipes and L. fabarum) of each of the species of aphid separately. Secondly, we investigated the acceptance behaviour of the parasitoids when both aphid species were present, as would be the case in the field, to test whether the parasitoids would differ in their preference. Thirdly, we tested whether changing the host plant would affect the host acceptance of the parasitoid.

\section{MATERIALS AND METHODS}

The aphid A. fabae was obtained from the Laboratory of Functional and Evolutive Entomology (ULg, Gembloux) in Belgium and was reared continuously in small pots containing bean plants (Vicia fabae). The aphid M. persicae was provided by Viridaxis S.A., Belgium and was reared continuously on sweet pepper plants (Capsicum annuum) variety Napoli. Aphids were maintained in wooden cages $(50 \times 50 \times 50 \mathrm{~cm})$ in climate rooms at 20 $\pm 1{ }^{\circ} \mathrm{C}, 60 \pm 10 \% \mathrm{RH}$ and a photoperiod of $16 \mathrm{~L}: 8 \mathrm{D}$.

Strains of the parasitoids $A$. colemani and $L$. testaceipes were provided by Viridaxis S.A., while the parasitoid L. fabarum (thelytokous strain IL07-64), was obtained from Professor C. Vorburger (Institute of Integrative Biology, Zurich). The parasitoid A. colemani was reared on the aphid M. persicae fed on sweet pepper. L. testaceipes and L. fabarum were reared on the aphid A. fabae fed on bean plants. We used the same host plants. Mummies of the three parasitoids obtained from the suppliers twice in order to refresh our cultures. The Viridaxis S.A Company also refreshes their rearing stocks regularly. The three parasitoids were maintained in climate rooms at $22 \pm 1{ }^{\circ} \mathrm{C}, 60 \pm 10 \% \mathrm{RH}$ and a photoperiod of $16 \mathrm{~L}: 8 \mathrm{D}$. Cohorts of parasitoids were produced by exposing second instar $M$. persicae to 2-3 day-old females of $A$. colemani (1 pair per 50 aphids), 2 nd instar $A$. fabae to 2-3 day-old female wasps of $L$. testaceipes ( 1 pair per 10 aphids) and L. fabarum ( 1 female for 10 aphids) in a $50 \times 50 \times 30 \mathrm{~cm}$ wooden cage for $24 \mathrm{~h}$. Eight to twelve days later, mummies were carefully removed from plants by scraping them gently off the leaves and kept individually in gelatine capsules until emergence. The emerged adults were fed with diluted honey. A male and a female of each species were put in small Petri dishes and observed until the end of copulation. Mated females were then used in the experiments. 


\section{Behavioural bioassay}

For the host preference test, 15 females each of $A$. colemani and L. testaceipes (mated) and 15 females of L. fabarum, aged $\leq 24$ $\mathrm{h}$, were exposed individually for 15 min to a group of 20 aphids (L3). There were three treatments: 20 individuals of $A$. fabae reared on bean, 20 individuals of $M$. persicae reared on sweet pepper, or 10 individuals of each aphid species mixed together. To analyze the influence of plant species on choice of aphid by the parasitoids, two host plants were tested: sugar beet and bean. The experiment was repeated 15 times for each plant species, during which each female was observed individually. The aphids were placed on $1 \mathrm{~cm}$ diameter leaf discs in glass petri dishes of 5 $\mathrm{cm}$ diameter. The experimental arena was placed on a light table (2500 LUX) in a dark room at $20 \pm 1{ }^{\circ} \mathrm{C}$. In all experiments, we recorded the number of antennal contacts and the number of ovipositor insertions (stings). It was not possible to distinguish between simple probing and ovipositor insertions (stings) that led to egg deposition, because oviposition took approximately $1.4 \mathrm{~s}$ (Marullo, 1987; Völkl \& Mackauer, 2000). After each 15 min observation, all aphids were transferred and reared under controlled conditions $\left(22 \pm 1{ }^{\circ} \mathrm{C}, 60 \pm 10 \%\right.$ R.H $)$ on fresh bean plant leaves for 12 days, until mummification. Leaves were placed on cotton soaked with water in plastic Petri dishes, the lids of which had openings in the centre covered by mesh for ventilation. We used leaves of bean since it is a suitable host for both aphid species, and is easier to use in Petri dishes than leaves of sugar beet.

Host acceptance is expressed as the number of ovipositor insertions recorded for a parasitoid divided by the number of antennal contacts and expressed as a percentage as in Acebes \& Messing (2013). In their case, they distinguished between acceptance and oviposition, which is the deposition of an egg inside the host. In our case, true oviposition could not be determined as the oviposition process takes less than one second and is similar to a sting without egg deposition. Suitability is the number of mummies divided by the number of attempts at ovipositor insertion expressed as a percentage. Emergence is the number of emerged parasitoid wasps divided by the total number of mummies expressed as a percentage.

\section{Statistical analyses}

Host acceptance, and host suitability were analyzed using Generalized Linear models based on a quasibinomial distribution (i.e. for overdispersed binomial data expressed as proportions) and a logit link function (Crawley, 1993), including parasitoid species, host species and host plant as fixed factors with interactions. Significant results at $p<0.05$ were followed by the use of Tukey HSD post-hoc multiple comparison tests using the Agricolae package (Mendiburu, 2015). Data are presented as means ( \pm SE). Statistical analyses were done using the statistical software $\mathrm{R}$ version 2.15.2 (R Development Core Team, 2012). Emergence values are cited in the text without statistical analysis, since no mummies were recorded in four of the replications of L. fabarum attacking the aphid $M$. persicae on beet and bean individually, and only one emergence from one mummy from $M$. persicae on both beet and bean plants.

\section{RESULTS}

\section{Host acceptance}

A. colemani accepted both species of aphid: A. fabae (approximately 43 and $46 \%$ ) and $M$. persicae (approximately 43 and $46 \%$ ) on beet and bean plants, respectively. The parasitoid $L$. testaceipes accepted $A$. fabae (approximately 50 and $89 \%$ ) more frequently than $M$. persicae (approximately 17 and $13 \%$ ) on both beet and bean plants, respec-

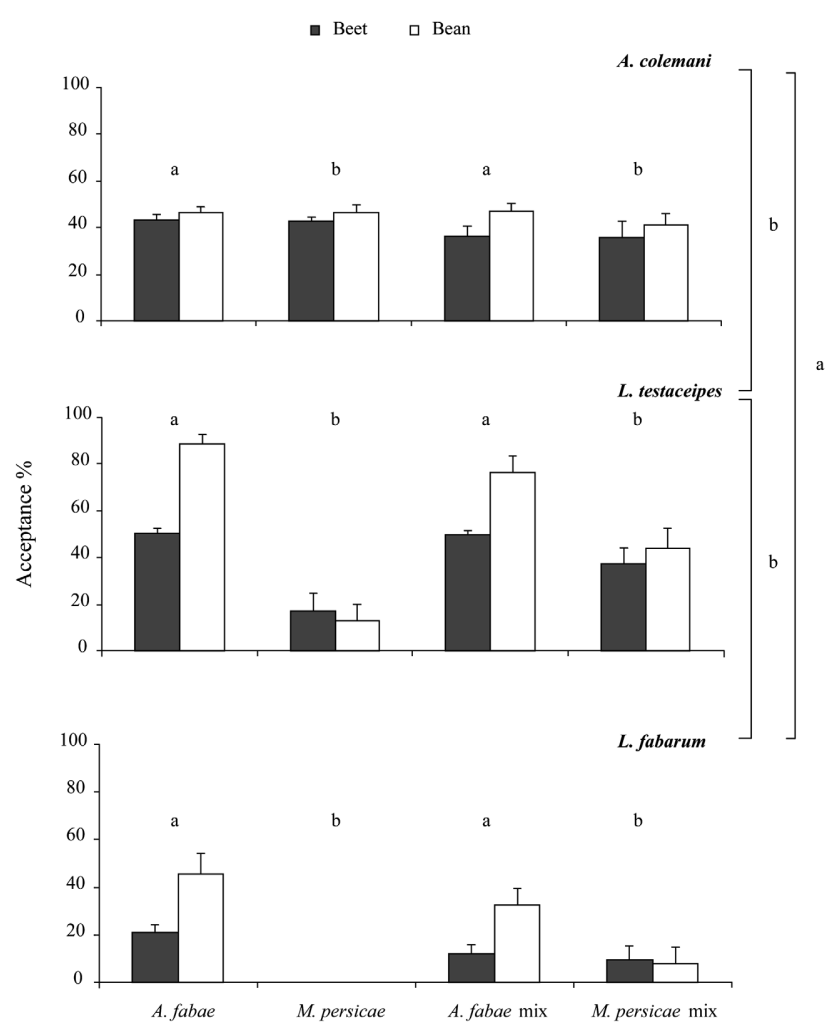

Fig. 1. Host acceptance (mean $\pm \mathrm{SE}$ ) expressed as a percentage of the different aphids accepted by the three parasitoids: $A$. colemani, $L$. testaceipes and $L$. fabarum on both plants (bean and beet) and in three combinations of aphids ( $A$. fabae, M. persicae and a mixture of $A$. fabae and $M$. persicae, results presented separately for each species of aphid). Small letters indicate significant differences in the main factors (parasitoid species and aphid hosts at $p$ $<0.05)$.

tively, but with a stronger preference on bean plants (Fig. 1). L. fabarum accepted only A. fabae (approximately 21 and $45 \%$ ) on both beet and bean plants, respectively (Fig. 1). L. fabarum accepted $M$. persicae (beet $=9$ and bean $=$ $8 \%$ ) only when it was mixed with $A$. fabae (Fig. 1).

Host acceptance varied among the parasitoid species $\left(F_{2,336}=70.56 ; p<0.001\right)$. L. testaceipes and A. colemani accepted both aphid species while $L$. fabarum accepted $M$. persicae only in the presence of $A$. fabae. Host acceptance also varied according to aphid species $\left(F_{3,336}=31.16 ; p<\right.$ $0.001), A$. fabae was always accepted more readily than $M$. persicae, whether aphids were separate or mixed. Plant host had a significant effect on the acceptance of these species of aphids $\left(F_{1,336}=23.94 ; p<0.001\right)$. Aphids on bean leaves were accepted more readily than those on beet leaves, particularly by L. testaceipes (Table 1 ). Significant interactions were found between parasitoid and aphid, aphid and plant but not when the three factors were combined (Table 1).

\section{Suitability}

Suitability differed significantly among parasitoids $\left(F_{2,336}=15.17 ; p<0.001\right)$. For both aphid species, $A$. colemani produced more mummies per ovipositor contact than L. testaceipes and L. fabarum (Fig. 2). Significant differences were also recorded between aphid species, $A$. fabae being more suitable than $M$. persicae $\left(F_{3,336}=13.42 ; p<\right.$ 
Table 1. Results obtained using a general linear model to determine the effects of parasitoid species, host aphid and plant, and their interactions, on host acceptance and suitability.

\begin{tabular}{llrrc}
\hline Trait & Effect & DF & F & P value \\
\hline & Parasitoid & 2 & 70.56 & $<\mathbf{0 . 0 0 1}$ \\
& Aphid & 3 & 31.16 & $<\mathbf{0 . 0 0 1}$ \\
& Plant & 1 & 23.94 & $<\mathbf{0 . 0 0 1}$ \\
Host acceptance & Parasitoid: Aphid & 6 & 12.87 & $<\mathbf{0 . 0 0 1}$ \\
& Parasitoid: Plant & 2 & 2.26 & 0.10 \\
& Aphid: Plant & 3 & 3.16 & $\mathbf{0 . 0 2}$ \\
& Parasitoid: Aphid: Plant & 6 & 1.66 & 0.13 \\
& Residuals & 336 & & \\
\hline Parasitoid & 2 & 15.17 & $<\mathbf{0 . 0 0 1}$ \\
& Host & 3 & 13.42 & $<\mathbf{0 . 0 0 1}$ \\
Plant & 1 & 8.74 & $\mathbf{0 . 0 0 3}$ \\
& Parasitoid: Aphid & 6 & 6.39 & $<\mathbf{0 . 0 0 1}$ \\
Parasitoid: Plant & 2 & 1.11 & 0.33 \\
& Aphid: Plant & 3 & 0.13 & 0.94 \\
Parasitoid: Aphid: Plant & 6 & 0.26 & 0.95 \\
& Residuals & 336 & & \\
& & & &
\end{tabular}

0.001) particularly for L. fabarum. Plant host too had a significant effect on aphid suitability $\left(F_{1,336}=8.74 ; p=0.003\right)$. Parasitized aphids were allowed to continue their development on bean after the experiment no matter whether the parasitoid had had the choice of aphids on sugar beet or on bean. The difference in plant host suitability probably reflects the fact that on sugar beet ovipositor insertion was more frequently followed by egg laying than on bean. This
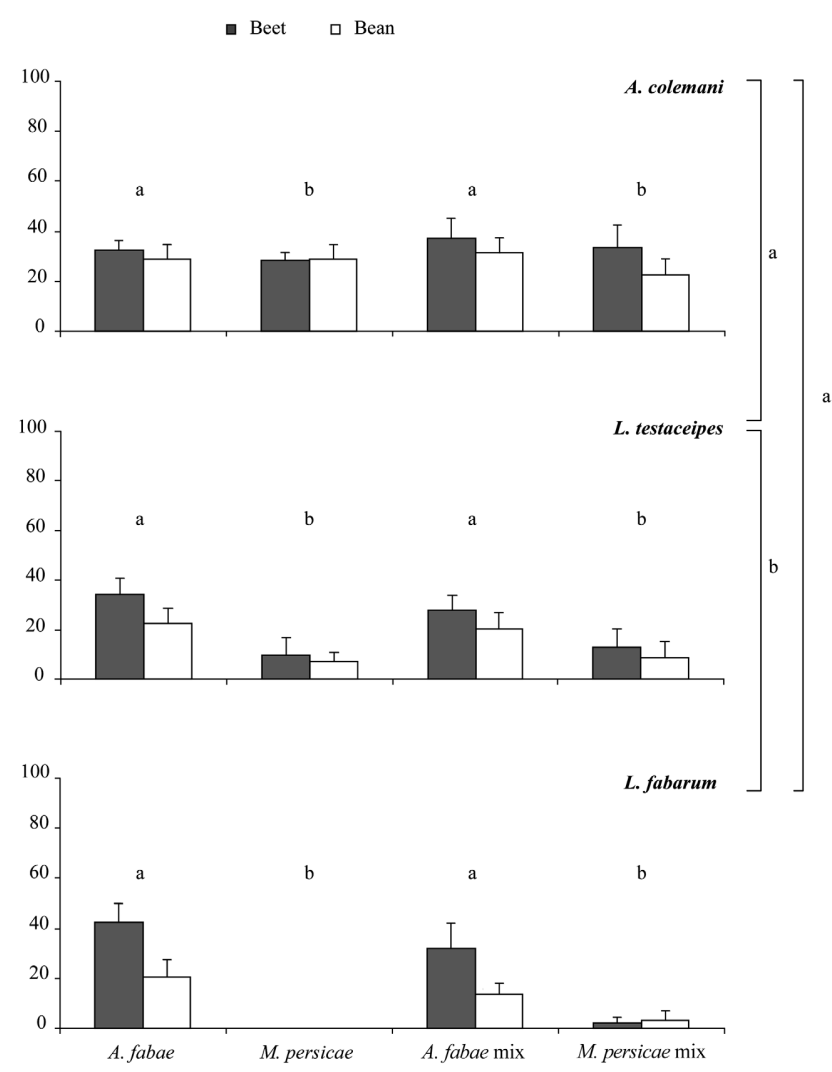

Fig. 2. Suitability (mean $\pm \mathrm{SE}$ ) expressed as a percentage recorded in the three combinations of aphids ( $A$. fabae, M. persicae, and mix $A$. fabae and $M$. persicae, results presented separately for each species of aphid) on both plants (bean and beat) for the three parasitoids: A.colemani, L. testaceipes and L. fabarum. Small letters indicate significant differences in the main factors (parasitoid species and aphid hosts at $p<0.05$ ).
๑ Beet $\square$ Bean
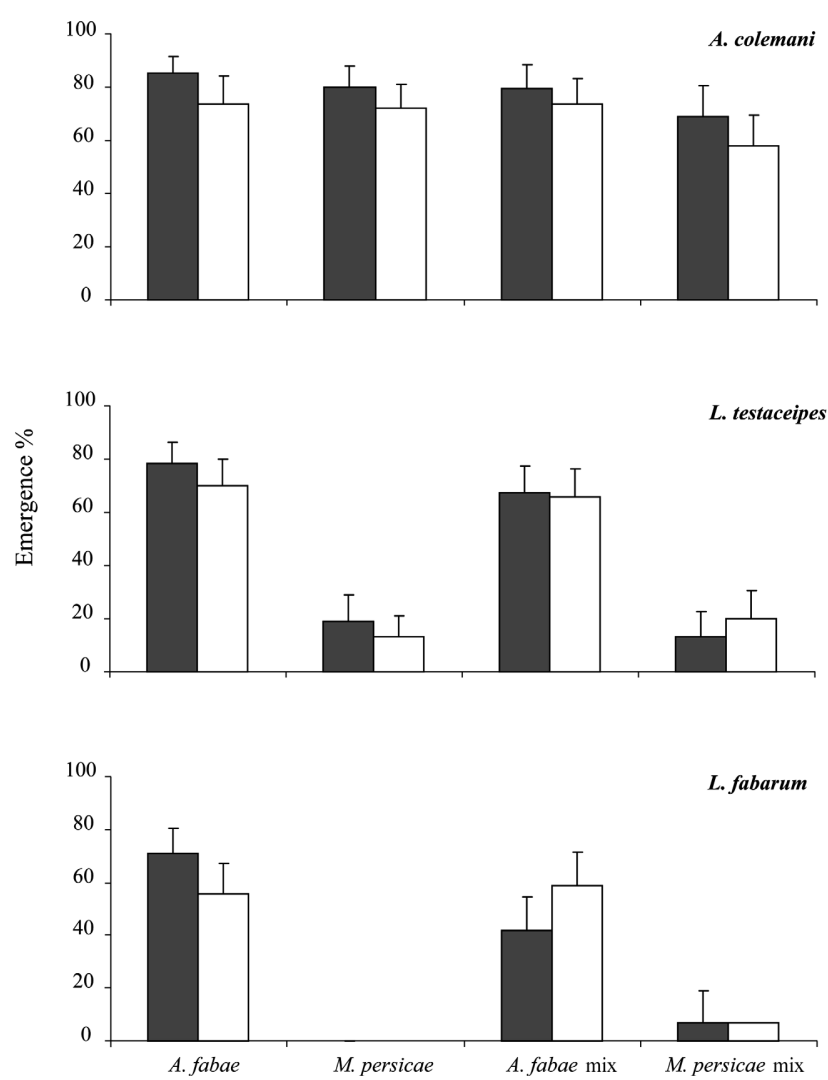

Fig. 3. Emergence (mean $\pm \mathrm{SE}$ ) expressed as a percentage of the three parasitoids: $A$. colemani, $L$. testaceipes and $L$. fabarum recorded for the three combinations of aphids ( $A$. fabae, M. persicae, and mixture of $A$. fabae and $M$. persicae, results presented separately for each species of aphid) on both plants (bean and beet).

is an interesting observation in the context of biological control. A significant interaction was found only between parasitoid and aphid (Table 1). The emergence from mummies in all the treatments is shown in (Fig. 3).

\section{DISCUSSION}

In this study we compared the acceptance and suitability of two species of aphids on two host plants: bean and beet, for three species of parasitoids. We did not manipulate their experience by rearing the parasitoids on each of these species of aphids. We chose to take into account the aphid species on which they are usually reared before release into the field, where they are likely be exposed to several potential host species. We found that $A$. colemani did not display any difference in its acceptance of these species of aphids on either host plant. Messing \& Rabasse (1995), using a strain of A. colemani reared on either M. persicae or Aphis gossypii, showed that $A$. gossypii was the preferred host twice as much as $M$. persicae, no matter which aphid was used for rearing the parasitoid. They interpreted this result as evidence of an innate preference of $A$. colemani for $A$. gossypii. They also record that parasitoids reared on $M$. persicae had a lower preference for $A$. gossypii. No such difference was recorded for $A$. colemani in our study. However we showed that $L$. testaceipes clearly preferred A. fabae, and this preference is enhanced on bean plants. 
$L$. fabarum did not accept $M$. persicae when presented on its own, but in the presence of $A$. fabae a $40 \%$ acceptance was recorded on sugar beet and less than $20 \%$ on bean. $L$. testaceipes also accepted a greater percentage of $M$. persicae in the presence of $A$. fabae. This could be a confusion effect linked to the close presence of a suitable host. In this case, chemical cues of the suitable host may have triggered the searching behaviour and acceptance of an unsuitable host (Meisner et al., 2007). The acceptance of $M$. persicae by $L$. testaceipes in the presence of $A$. fabae appeared to decrease, as fewer ovipositor contacts were recorded following antennal contact compared to when $M$. persicae was the only host present. This probably indicates a preference for $A$. fabae when a choice is possible. Suitability of $M$. persicae for L. testaceipes is particularly low considering that most mummies produced gave rise to an adult on bean plants and half of them on sugar beet. For L. fabarum, suitability of $A$. fabae seemed to be influenced by the host plant. Surprisingly, some L. fabarum adults emerged from the few $M$. persicae mummies recorded when a mixture of the two aphids was used.

Depending on the species of aphid and parasitoid and whether the aphids were presented alone or in a mixture, acceptance and suitability were modulated by the host plant. This is consistent with the results of previous studies, such as that of Grasswitz (1998). They show that a brief pre-flight experience of the aphid/plant combination resulted in a significant increase in the proportion of $A$. colemani females that responded to such a combination in a wind tunnel, compared to naive females. Damaged plants produce semiochemicals that can be detected by parasitoids and were tested in A. ervi (Du et al., 1998). Among the volatiles produced by plants in response to aphid attack, 6-methyl-5-hepten-2-one is identified as being primarily responsible for the attraction of $A$. ervi. In contrast, bean infested with $A$. fabae does not produce this volatile and attracted significantly fewer $A$. ervi, for which $A$. fabae is not a host (Du et al., 1996, Powell et al., 1998, Guerrieri et al., 1999).

In our study, the parasitoid $A$. colemani was the best in terms of acceptance, suitability and emergence on both species of aphids on both plants, followed by L. testaceipes and $L$. fabarum. The parasitoid $L$. testaceipes showed a preference and greater acceptance of $A$. fabae over $M$. persicae, when they were presented both individually and simultaneously, as well as on both host plants. A. colemani and $L$. testaceipes are generalists but with preferences for aphids on particular species of plants (Soglia et al., 2006, Silva et al., 2008). It is possible that preimaginal learning, such as contact with the mummy, may have occurred and determined host choice preference (van Emden et al., 2008). Changes in host acceptance that depend on planttype are recorded for other aphid parasitoids. Experimental studies show that L. testaceipes accepts more aphids on mung bean than on cotton (Hopkinson et al., 2013) and that A. rhopalosiphi more readily attacks its host $S$. avenae and non-host $M$. persicae on wheat than on Brussels sprouts (Brimah \& van Emden, 1994). A. colemani accepts a host more readily on cucumber than on eggplant (Messing \& Rabasse, 1995). However, when provided with a choice of odours on infested plants, $A$. colemani does not show any significant preference for the cultivar on which they were reared (Kalule \& Wright, 2004).

L. fabarum clearly prefers $A$. fabae and does not parasitize $M$. persicae. This may be related to colour, as this parasitoid prefers dark coloured aphids (Tregubenko, 1980). High suitability and emergence were recorded for $L$. fabarum attacking $A$. fabae on sugar beet. This is consistent with the results of Völkl \& Stechmann (1998), who record that the percentage parasitism of $A$. fabae by L. fabarum in the field is lower on broad bean than on other host plants, including fodder beet. It is possible that our results for suitability were influenced by the aphid host being reared only on broad bean before the experiments, particularly for $M$. persicae. This is important in an applied context, as the host aphid and host plant used in the mass rearing of the parasitoid are often different to those of the target aphid and the target plant host. Further investigation of crosses using several aphid hosts with several host plants would help to determine if rearing conditions change parasitoid preferences.

Host switching experiments suggest that the natal host of the parasitoid is important in host selection (Bourchier et al., 1994). It is possible that L. testaceipes prefers to lay its eggs on the host on which it was reared (Vinson, 1998). The wasps that had $A$. fabae - broad bean as a natal host combination parasitized $A$. fabae on broad bean (positive conditioning), while their performance on $A$. fabae - beet was variable, and they largely avoided the host combination they were reared on (negative conditioning). We obtained similar results for $L$. testaceipes, as the greatest acceptance of $A$. fabae was recorded on bean, which was also the rearing plant. In contrast, Hopkinson et al. (2013) record that $A$. craccivora on mung bean is accepted more frequently by $L$. testaceipes than $A$. gossypii on cotton.

Bilu et al. (2006) record that A. colemani shows positive conditioning to $M$. persicae on peppers and negative conditioning to $R$. padi on wheat. However, their experiments were done using whole plants in a choice design and thus the conditioning effect included the attraction effect of the whole system, plant + host, and the suitability for the mummy's development. As parasitoids show a preference for the plant on which they were reared, this is most likely the consequence of conditioning. In our study attraction could play only a minor role as leaves, rather than whole plants, were used in the behavioural experiments.

Our results show that the choice of aphid by parasitoids depends not only on the species of aphid but also on the plant and previous rearing history. In sugar beet crops, the parasitoid $A$. colemani is able to attack the two main aphid species, $A$. fabae and $M$. persicae, which may be present simultaneously in the same field and even on the same plant. This makes it a good candidate for biological control of aphids on sugar beet, while L. testaceipes is limited mostly to $A$. fabae. However, the potential synergistic or competitive effects of the two parasitoid species on the growth of 
both aphid populations should be analyzed in field trials, particularly where the aphids are mixed, in order to better understand the consequences of the confusion effect.

ACKNOWLEDGEMENTS. This study was supported by a PhD fellowship from Université catholique de Louvain in Belgium. We thank G. Le Goff for his comments on the statistical analyses. We are grateful to M. Brooks for improving the English of the manuscript. We also thank C. Vorburger (Institute of Integrative Biology, Zurich) for providing the parasitoid L. fabarum, and Viridaxis S.A. in Belgium for providing the parasitoids $A$. colemani and L. testaceipes. This publication is $348 \mathrm{BRC}$ of the Biodiversity Research Centre.

DISCLOSURE. The authors declare that they have no conflict of interest.

\section{REFERENCES}

Acebes A.L. \& Messing R.H. 2013: Host range of a newly introduced parasitoid, Binodoxys communis among common aphid species in Hawaii. - BioControl 58: 635-644.

Bilu E., Hopper K.R. \& Coll M. 2006: Host choice by Aphidius colemani: effects of plants, plant-aphid combinations and the presence of intra-guild predators. - Ecol. Entomol. 31: 331336.

Boivin G., Hance T. \& Brodeur J. 2012: Aphid parasitoids in biological control. - Can. J. Plant Sci. 92: 1-12.

Bonnemain J.L. 2010: Aphids as biological models and agricultural pests. - C. R. Biol. 333: 461-463.

Bourchier R.S., SMith S.M., Corrigan J.E. \& Laing J.E. 1994: Effect of host switching on performance of mass reared Trichogramma minutum. - Biocontr. Sci. Techn. 4: 353-362.

Bragard C., Caciagli P., Lemaire O., Lopez-Moya J.J., Macfarlane S., Peters D., Susi P. \& Torrance L. 2013: Status and prospects of plant virus control through interference with vector transmission. - Annu. Rev. Phytopathol. 51: 177-201.

Brimah H. \& van EMdEN H.F. 1994: The role of the plant in host acceptance by the parasitoid Aphidius rhopalosiphi (Hymenoptera, Braconidae). - Bull. Entomol. Res. 84: 303-306.

Carver M. \& Franzmann B. 2001: Lysiphlebus Forster (Hymenoptera: Braconidae: Aphidiinae) in Australia. - Aust. J. Entomol. 40: 198-201.

Chau A. \& Mackauer M. 2001: Preference of the aphid parasitoid Monoctonus paulensis (Hymenoptera: Braconidae, Aphidiinae) for different aphid species: Female choice and offspring survival. - Biol. Contr. 20: 30-38.

Clover G.R.G., Azam-Ali S.N., Jaggard K.W. \& Smith H.G. 1999: The effects of beet yellows virus on the growth and physiology of sugar beet (Beta vulgaris). - Plant Pathol. 48: 129-138.

Crawley M.J. 1993: GLIM for Ecologists. Blackwell Scientific Publications Oxford, $304 \mathrm{pp}$.

Desneux N., Barta R.J., Hoelmer K.A., Hopper K.R. \& Heimpel G.E. 2009: Multifaceted determinants of host specificity in an aphid parasitoid. - Oecologia 160: 387-398.

Dicke M., De Boer J.G., Hofte M. \& Rocha-Granados M.C. 2003: Mixed blends of herbivore-induced plant volatiles and foraging success of carnivorous arthropods. - Oikos 101: $38-48$.

Dorn S., Schumacher P., Abivardi C. \& Meyhofer R. 1999: Global and regional pest insects and their antagonists in orchards: spatial dynamics. - Agri. Ecosyst. Environ. 73: 111-118.

Du Y.J., Poppy G.M. \& Powell W. 1996: Relative importance of semiochemicals from first and second trophic levels in host foraging behavior of Aphidius ervi. - J. Chem. Ecol. 22: 1591-1605.

Du Y.J., Poppy G.M., Powell W., Pickett J.A., Wadhams L.J. \& Woodcock C.M. 1998: Identification of semiochemicals released during aphid feeding that attract parasitoid Aphidius ervi. - J. Chem. Ecol. 24: 1355-1368.

Duffus J.E. 1971: Role of weeds in the incidence of virus disease. - Annu. Rev. Phytopathol. 9: 319-330.

Fernandez-Quintanilla C., Fereres A., Godfrey L. \& Norris R.F. 2002: Development and reproduction of Myzus persicae and Aphis fabae (Hom., Aphididae) on selected weed species surrounding sugar beet fields. - J. Appl. Entomol. 4: 198-202.

Grasswitz T.R. 1998: Effect of adult experience on the host-location behavior of the aphid parasitoid Aphidius colemani Viereck (Hymenoptera: Aphidiidae). — Biol. Contr. 12: 177-181.

Guerrieri E., Poppy G.M., Powell W., Tremblay E. \& PennacCHIO F. 1999: Induction and systemic release of herbivore-induced plant volatiles mediating in flight orientation of Aphidius ervi. - J. Chem. Ecol. 25: 1247-1261.

Hatano E., Kunert G., Michaud J.P. \& Weisser W.W. 2008: Chemical cues mediating aphid location by natural enemies. - Eur. J. Entomol. 105: 797-806.

Hopkinson J.E., ZaLUCKI M.P. \& MurRaY D.A.H. 2013: Host selection and parasitism behavior of Lysiphlebus testaceipes: Role of plant, aphid species and instar. - Biol. Contr. 64: 283-290.

Hopper K.R., Prager S.M. \& Heimpel G.E. 2013: Is parasitoid acceptance of different host species dynamic? - Funct. Ecol. 27: 1201-1211.

JADOT R. 1974: Etude de l'épidémiologie des virus de la jaunisse de la betterave. V. Les plantes rudérales sources de jaunisse grave ou de jaunisse modérée. - Parasitica 30: 37-44.

JADOT R. \& RoLAND G. 1971: Observations sur les déplacements des aphids à partir des plantes adventices marquées dans un champ de betteraves. - Meded. Fac. Landbouw. Rijksuniv. Gent 36: 940-944.

Jang E.B., Messing R.H., Klungness L.M. \& Carvalho L.A. 2000: Flight tunnel responses of Diachasmimorpha longicaudata (Ashmead) (Hymenoptera: Braconidae) to olfactory and visual stimuli. - J. Insect Behav. 13: 525-538.

Kalule T. \& Wright D.J. 2004: The influence of cultivar and cultivar-aphid odours on the olfactory response of the parasitoid Aphidius colemani. - J. Appl. Entomol. 128: 120-125.

KNIGHT P. 1944: Insects associated with the Palay rubber vine in Haiti. - J. Econ. Entomol. 37: 100-102.

Larocca A., Fanti P., Romano V.A., Marsicovetere E., Isidoro N., Romani R., Ruschioni S., Pennacchio F. \& Battaglia D. 2007: Functional bases of host-acceptance behaviour in the aphid parasitoid Aphidius ervi. — Physiol. Entomol. 32: 305312.

Levie A., Legrand M.A., Dogot P., Pels C., Baret P.V. \& Hance T. 2005: Mass releases of Aphidius rhopalosiphi (Hymenoptera: Aphidiinae), and strip management to control of wheat aphids. - Agric. Ecosyst. Environ. 105: 17-21.

Mackauer M. \& Stary P. 1967: Ichneumonoidea, world Aphidiidae. In Delucchi V. \& Rémaudière G. (eds): Index of Entomophagous Insects. Le François, Paris, pp. 1-167.

Marullo R. 1987: Confronto biologico tra due specie diendoparassitoidi di Afidi, Lysiphlebus testaceipes (Cresson) e Lysiphlebus fabarum (Marshall) (Hym. Braconidae). - Boll. Lab. Entomol. Agr. Filippo Silvestri 44: 81-96.

Mattiacci L., Dicke M. \& Posthumus M.A. 1994: Induction of parasitoid attracting synomone in brussels sprouts plants by feeding of Pieris brassicae larvae: role of mechanical damage and herbivore elicitor. - J. Chem. Ecol. 20: 2229-2247. 
Meisner M., Harmon J.P. \& Ives A.R. 2007: Presence of an unsuitable host diminishes the competitive superiority of an insect parasitoid: a distraction effect. - Popul. Ecol. 49: 347-355.

Mendiburu F. 2015: Agricolae - Statistical Procedures for Agricultural Research. Version 1.2-2. URL: http://tarwi.lamolina. edu.pe/ fmendiburu.

Messing R.H. \& Rabasse J.M. 1995: Oviposition behavior of the polyphagous aphid parasitoid Aphidius colemani viereck (Hymenoptera, Aphidiidae). - Agric. Ecosyst. Environ. 52: 13-17.

Muratori F., Le Ralec A., Lognay G. \& Hance T. 2006: Epicuticular factors involved in host recognition for the aphid parasitoid Aphidius rhopalosiphi. - J. Chem. Ecol. 32: 579-593.

Nemec V. \& Stary P. 1985: Population diversity in deuterotokous Lysiphlebus species, parasitoids of aphids (Hymenoptera, Aphidiidae). - Acta Entomol. Bohemoslov. 82: 170-174.

Ode P.J., Hopper K.R. \& Coll M. 2005: Oviposition vs. offspring fitness in Aphidius colemani parasitizing different aphid species. - Entomol. Exp. Appl. 115: 303-310.

Powell W., Pennacchio F., Poppy G.M. \& Tremblay E. 1998: Strategies involved in the location of hosts by the parasitoid Aphidius ervi Haliday (Hymenoptera: Braconidae: Aphidiinae). - Biol. Contr. 11: 104-112.

Rasekh A., Michaud J.P., Allahyari H. \& Sabahi Q. 2010: The foraging behavior of Lysiphlebus fabarum (Marshall), a thelytokous parasitoid of the black bean aphid in Iran. $-J$. Insect Behav. 23: 165-179.

SeKhar P.S. 1960: Host relationships of Aphidius testaceipes (Cresson) and Praon aguti (Smith), primary parasites of aphids. - Can. J. Zool. 38: 593-603.

Silva R.J., Bueno V.H.P. \& SAmpaio M.V. 2008: Quality of different aphids as hosts of the parasitoid Lysiphlebus testaceipes (Cresson) (Hymenoptera: Braconidae: Aphidiinae). - Neotrop. Entomol. 37: 173-179.

Simpson K.L.S., Jackson G.E. \& Grace J. 2012: The response of aphids to plant water stress - the case of Myzus persicae and Brassica oleracea var. capitata. - Entomol. Exp. Appl. 142: 191-202.

Smith H.G. \& Hallsworth P.B. 1990: The effects of yellowing viruses on yield of sugar beet in field trials, 1985 and 1987. Ann. Appl. Biol. 116: 503-511.

Smith H.G., Stevens M. \& Hallsworth P.B. 1991: The use of monoclonal-antibodies to detect beet mild yellowing virus and beet western yellows virus in aphids. - Ann. Appl. Biol. 119: 295-302.
Soglia N.C.M., Bueno V.H.P., SAmpaio M.V., Rodrigues S.M.M. \& LEDO C.A.S. 2006: Development and parasitism of Lysiphlebus testaceipes (Cresson) and Aphidius colemani Viereck (Hymenoptera: Braconidae) on Aphis gossypii Glover (Hemiptera: Aphididae) on two chrysanthemum cultivars. - Neotrop. Entomol. 35: 364-370.

StARY P. 1975: Aphidius colemani Viereck: its taxonomy, distribution, and host range. - Acta Entomol. Bohemoslov. 72: $156-163$.

TregubenKo E.S. 1980: On the ethology of aphids and aphidophagous insects. - Zashch. Rastenii 4: 38-39.

Turlings T.C.J., Tumlinson J.H. \& Lewis W.J. 1990: Exploitation of herbivore-induced plant odors by host-seeking parasitic wasps. - Science 250: 1251-1253.

Turpeau E., Hullé M. \& Chaubet B. 2010: Encyclop'Aphid. URL: https://www6.inra.fr/encyclopedie-pucerons.

van Emden H.F., Storeck A.P., Douloumpaka S., Eleftherianos I., Poppy G.M. \& Powell W. 2008: Plant chemistry and aphid parasitoids (Hymenoptera: Braconidae): Imprinting and memory. - Eur. J. Entomol. 105: 477-483.

Vinson S.B. 1976: Host selection by insect parasitoids. - Annu. Rev. Entomol. 21: 109-133.

VINSON S.B. 1984: Parasitoid-host relationships. In Bell W.J. \& Cardes R. (eds): The Chemical Ecology of Insects. Chapman and Hall, New York, pp. 205-233.

VINSON S.B. 1998: The general host selection behavior of parasitoid Hymenoptera and a comparison of initial strategies utilized by larvaphagous and oophagous species. - Biol. Contr. 11: 79-96.

VöLKL W. 1992: Aphids or their parasitoids - who actually benefits from ant-attendance. - J. Anim. Ecol. 61: 273-281.

VöLKL W. \& Stechmann D.H. 1998: Parasitism of black bean aphid (Aphis fabae) by Lysiphlebus fabarum (Hym., Aphidiidae): The influence of host plant and habitat. - J. Appl. Entomol. 122: 201-206.

VölKL W. \& MackaUer M. 2000: Oviposition behavior of aphidiine wasps (Hymenoptera: Braconidae, Aphidiinae): morphological adaptations and evolutionary trends. - Can. Entomol. 132: 197-212.

Wellings P.W., Ward S.A., Dixon A.F.G. \& Rabbinge R. 1989: Crop loss assessment. In Minks A.K. \& Harrewijns P. (eds): Aphids, their Biology, Natural Enemies and Control, Vol. 2C. Elsevier, Amsterdam, pp. 49-69.

Received April 11, 2016; revised and accepted September 19, 2016 Published online October 27, 2016 